\title{
Lishizhenia caseinilytica gen. nov., sp. nov., a marine bacterium of the phylum Bacteroidetes
}

Correspondence

Ken W. K. Lau

sslwk@ust.hk

\author{
Ken W. K. Lau, ${ }^{1}$ Jianping Ren, ${ }^{1}$ Natalie L. M. Wai, ${ }^{2}$ Pei-Yuan Oian, ${ }^{1}$ \\ Po-Keung Wong ${ }^{2}$ and Madeline $\mathrm{Wu}^{1}$
${ }^{1}$ Department of Biology, The Hong Kong University of Science and Technology, Clear Water Bay, Kowloon, Hong Kong, SAR, People's Republic of China
${ }^{2}$ Department of Biology, The Chinese University of Hong Kong, Shatin, NT, Hong Kong, SAR, People's Republic of China

\begin{abstract}
A light-orange, aerobic bacterium, strain UST040201-001 ${ }^{\top}$, that degrades casein, gelatin and Tween 20, was isolated in February 2004 from a sand-filtered seawater sample from Port Shelter, Hong Kong SAR, China. The strain possessed menaquinone- 6 and its $16 \mathrm{~S}$ rRNA gene sequence shared only $90 \cdot 1 \%$ similarity with that of Brumimicrobium glaciale IC $156^{\top}$. Phylogenetic analysis showed that UST040201-001 ${ }^{\top}$ formed a distinct lineage within the family Cryomorphaceae. Its ecophysiological and biochemical characteristics suggest that this strain represents a novel genus and species within the phylum Bacteroidetes. The name Lishizhenia caseinilytica gen. nov., sp. nov. is proposed. The type strain of Lishizhenia caseinilytica is UST040201-001 ${ }^{\top}$ (=NRRL B$41434^{\top}=$ JCM $13821^{\top}$ ).
\end{abstract}

Bowman et al. (2003) established the family Cryomorphaceae in the phylum Bacteroidetes based on a polyphasic taxonomic approach. The Cryomorphaceae encompasses four marine genera, Brumimicrobium, Cryomorpha, Crocinitomix and Owenweeksia, and a recently described freshwater genus, Fluviicola, which form a distinct clade in the class Flavobacteria, branching between the families Flavobacteriaceae and Bacteroidaceae (Bowman et al., 2003; Lau et al., 2005; O'Sullivan et al., 2005). Members of the Cryomorphaceae cannot utilize carbohydrates and require complex organic compounds for growth (Bowman et al., 2003; Lau et al., 2005; O'Sullivan et al., 2005). Molecular phylogenetic studies have found that phylotypes related to the Cryomorphaceae are associated with phytoplankton blooms (Pinhassi et al., 2004; Grossart et al., 2005).

A seawater sample was collected in February 2004 from the outlet of a tank storing sand-filtered seawater that was pumped from $5 \mathrm{~m}$ depth adjacent to the Coastal Marine Laboratory of Hong Kong University of Science and Technology. Aliquots of $100 \mu \mathrm{l}$ were spread onto YPS-SW agar (Lau et al., 2005) and incubated at $30^{\circ} \mathrm{C}$ for 3 days. Pigmented colonies were selected and then purified by repeatedly restreaking on YPS-SW agar. These isolates were grown in marine broth 2216 (MB; Difco) and stored in MB

The GenBank/EMBL/DDBJ accession number for the 16S rRNA gene sequence of strain UST040201-001 ${ }^{\top}$ is AB176674.

A photograph showing colony morphology and phase-contrast and scanning electron micrographs of strain UST040201-001 ${ }^{\top}$ are available as supplementary material in IJSEM Online. supplemented with $50 \%(\mathrm{v} / \mathrm{v})$ glycerol at $-80^{\circ} \mathrm{C}$. The isolates were subjected to partial $16 \mathrm{~S}$ rRNA gene sequencing and one isolate, UST040201-001 ${ }^{\mathrm{T}}$, shared only $90 \%$ sequence similarity with its nearest relative, Crocinitomix catalasitica NCIMB $1418^{\mathrm{T}}$. We further characterized this novel bacterium and determined its taxonomic position by using the polyphasic approach and propose that strain UST040201-001 ${ }^{\mathrm{T}}$ represents a novel species of a new genus in the family Cryomorphaceae.

We observed colony morphology on plates of marine agar 2216 (MA; Difco) that had been incubated at $30^{\circ} \mathrm{C}$ for 5 days. Cell size and gliding motility were examined using a Zeiss MC100 Spot microscope at $\times 1000$ magnification. To study surface morphology, we collected cells from an overnight culture that were then washed in PBS, fixed overnight in $2.5 \%$ glutaraldehyde, dehydrated in ethanol, dried in a critical-point drier and coated with gold before being examined under a scanning electron microscope (JOEL JSM 6300F). The Gram-reaction was assessed according to Collins et al. (1989). Growth under different conditions was monitored by measuring the optical density at $600 \mathrm{~nm}$ with a spectrophotometer and the range giving the highest cell yield was taken as the optimum. Growth was evaluated at various temperatures $(4,16,20,25,30,33,37$, 40 and $42{ }^{\circ} \mathrm{C}$ ) in artificial seawater (ASW; Lewin \& Lounsbery, 1969) containing $0.4 \%$ yeast extract (ASWY). Growth at various $\mathrm{pH}$ values $(\mathrm{pH} 3 \cdot 0,4 \cdot 0,5 \cdot 0,6 \cdot 0,7 \cdot 0,8 \cdot 0$, $9 \cdot 0$ or $10 \cdot 0$ ) was evaluated in YP-SW medium (Lau et al., 2005) adjusted with $1 \mathrm{M} \mathrm{HCl}$ or $\mathrm{NaOH}$. Salinity tolerance was determined in YP-SW prepared with 0, 5, 15, 20, 40, 75 
or $100 \%$ filtered seawater. Salt requirement and tolerance were tested in ASWY with $\mathrm{NaCl}$ added at $0,1,2,3,4,5,7 \cdot 5$, 10 or $15 \%(\mathrm{w} / \mathrm{v})$. Anaerobic growth was examined in the Oxoid anaerobic system on YP-SW agar supplemented with $0 \cdot 1 \% \mathrm{NaNO}_{3}, 0 \cdot 1 \%$ glucose or $0 \cdot 1 \%$ meat extract. Acid production from carbohydrates was determined using API 50CH strips (bioMérieux), using a medium composed of $50 \% \mathrm{CHB} / \mathrm{E}$ medium (bioMérieux) with $0.075 \%$ $\mathrm{CaCl}_{2} \cdot 2 \mathrm{H}_{2} \mathrm{O}, \quad 1 \cdot 875 \% \quad \mathrm{NaCl}$ and $0.375 \% \quad \mathrm{MgCl}_{2}$. Carbohydrate assimilation was determined using API $50 \mathrm{CH}$ strips, using ASW supplemented with $0.05 \%$ yeast extract for resuspension of cells, and the strips were incubated at $30^{\circ} \mathrm{C}$ for 2 weeks. Tests for fermentation of $\mathrm{D}(+)$-glucose, $\mathrm{D}(-)$-mannitol and sucrose and hydrolysis of alginate, chitin and Tweens 20, 40, 60 and 80 were carried out according to Baumann \& Baumann (1981). The activities of catalase, oxidase, lecithinase and nitrate reductase, indole production, $\mathrm{H}_{2} \mathrm{~S}$ generation from cysteine or thiosulfate and hydrolysis of casein, cellulose, starch and gelatin were examined according to Smibert \& Krieg (1994). $\beta$-Galactosidase activity was examined according to Gosink et al. (1998). DNA hydrolysis was determined according to Lau et al. (2005). Haemolytic activity was investigated using defibrinated rabbit blood $(5 \%, \mathrm{v} / \mathrm{v})$ prepared with blood agar base (BBL) using filtered seawater or double-distilled water. Degradation of dead yeast cells was tested on VY/2 agar (Reichenbach, 1989) prepared with $100 \%$ filtered seawater.

The absorption spectrum was determined by extraction of a $48 \mathrm{~h}$ YP-SW culture with absolute ethanol and scanning the extract from 300 to $700 \mathrm{~nm}$ with a Beckman DU650 spectrophotometer. The bathochromatic shift test for flexirubin was performed by addition of $20 \% \mathrm{KOH}$ (Fautz \& Reichenbach, 1980). Isoprenoid quinone analysis was performed by the HPLC method (Collins, 1994), using menaquinones extracted from Cytophaga lytica (Nakagawa \& Yamasato, 1993) as the MK-6 reference. Fatty acid methyl ester analysis was determined by the MIDI Sherlock Microbial Identification System (Microbial ID) with cells grown on $\mathrm{MA}$ in $12^{\circ} \mathrm{C}$ for 5 days. Genomic DNA was extracted using the TaKaRa MiniBEST bacterial genomic DNA extraction kit and the DNA base composition was determined by the HPLC method (Mesbah et al., 1989). The $16 \mathrm{~S}$ rRNA gene was amplified by using the primer pair 27F (5'-AGAGTTTGATCCTGGCTCAG-3') and 1525R (5'AAGGAGTGWTCCARCC-3') (Lane, 1991) with Vent DNA polymerase (NEB) and sequenced using an Applied Biosystems 3100 automated DNA sequencer. Related 16S rRNA gene sequences were retrieved from the NCBI nucleotide database after MEGABLAST search (Zhang et al., 2000). Sequences of strain UST040201-001 ${ }^{\mathrm{T}}$ and related strains were aligned by using CLUSTAL X (Thompson et al., 1997) and the alignment was edited by using the BioEdit sequence alignment editor version 5.0.9 (Hall, 1999; http:// www.mbio.ncsu.edu/BioEdit/bioedit.html). Evolutionary distances were computed using Kimura's two-parameter model (Kimura, 1980) and phylogenetic trees were
Table 1. Phenotypic features of strain UST040201-001

The strain did not form acid from or utilize the following carbohydrates: D-glucose, dextran, glycerol, erythritol, D- and L-arabinose, D-ribose, $\mathrm{D}$ - and L-xylose, D-adonitol, methyl $\beta$-D-xylopyranoside, D-galactose, D-fructose, D-mannose, L-sorbose, L-rhamnose, dulcitol, inositol, D-mannitol, D-sorbitol, methyl $\alpha$-D-mannopyranoside, methyl $\alpha$-D-glucopyranoside, $N$-acetylglucosamine, amygdalin, arbutin, aesculin, ferric citrate, salicin, D-cellobiose, D-maltose, Dlactose, D-melibiose, sucrose, D-trehalose, D-melezitose, D-raffinose, glycogen, xylitol, gentiobiose, D-turanose, D-lyxose, D-tagatose, Dand L-fucose, D- and L-arabitol, potassium gluconate, potassium 2-ketogluconate and potassium 5-ketogluconate. It was unable to ferment glucose, sucrose and mannitol.

\begin{tabular}{|lc|}
\hline Characteristic & Result \\
\hline Salinity range (\% seawater) & $15-100$ \\
Oxidase & + \\
Catalase & + \\
Nitrate reduction & - \\
Alkaline phosphatase & + \\
Arginine dihydrolase & - \\
$\beta$-Galactosidase & - \\
Lecithinase & - \\
Utilization of: & \\
Tween 20 & + \\
Gelatin & + \\
Agar & - \\
Casein & + \\
Cellulose & - \\
Chitin & - \\
DNA & - \\
Starch & - \\
Production of: & - \\
H 2 S & - \\
Indole & - \\
Hydrolysis of dead yeast cells & - \\
Haemolysis in rabbit blood agar & - \\
\end{tabular}

generated by MEGA version 2.1 (Kumar et al., 2001) using the neighbour-joining method (Saitou \& Nei, 1987) or the maximum-parsimony algorithm and evaluated by bootstrap analyses (Felsenstein, 1985) based on 1000 resamplings.

Cells of strain UST040201-001 $1^{\mathrm{T}}$ were rod-shaped $(0 \cdot 3-0 \cdot 5 \times 0 \cdot 5-3 \cdot 8 \mu \mathrm{m})$ and non-flagellated. Enlarged cells and filamentous cells were occasionally seen in stationary phase in broth culture. Colonies were $1 \cdot 0-2 \cdot 4 \mathrm{~mm}$ in diameter, light orange, circular, convex, smooth, glistening and translucent, with entire margins in MA after 5 days incubation at $30^{\circ} \mathrm{C}$. A photomicrograph showing colony morphology and phase-contrast and scanning electron micrographs are available as Supplementary Fig. S1 in IJSEM Online. Cells were motile by gliding in liquid culture but did not swarm on MA or YP-SW agar. UST040201-001 ${ }^{\mathrm{T}}$ was mesophilic, growing between 4 and $37^{\circ} \mathrm{C}$ with optimum growth at $27-30^{\circ} \mathrm{C}$. Growth occurred between $\mathrm{pH} 5 \cdot 0$ and 
Table 2. Whole-cell fatty acid profiles of UST040201-001 and members of the family Cryomorphaceae

Strains: 1, UST040201-001 ${ }^{\mathrm{T}} ;$ 2, Owenweeksia hongkongensis UST20020801 ${ }^{\mathrm{T}}$; 3, Brumimicrobium glaciale IC156 ${ }^{\mathrm{T}} ; 4$, Cryomorpha ignava $1-22^{\mathrm{T}} ; 5$, Crocinitomix catalasitica NCIMB $1418^{\mathrm{T}} ; 6$, Fluviicola taffensis RW262 ${ }^{\mathrm{T}}$. Data are from Bowman et al. (2003), Lau et al. (2005), O'Sullivan et al. (2005) and this study. UST040201-001 ${ }^{\mathrm{T}}$ and O. hongkongensis UST20020801 ${ }^{\mathrm{T}}$ were grown on MA at $12{ }^{\circ} \mathrm{C}$ for 5 days, Brumimicrobium glaciale $\mathrm{IC} 156^{\mathrm{T}}$, Cryomorpha ignava $1-22^{\mathrm{T}}$ and Crocinitomix catalasitica NCIMB $1418^{\mathrm{T}}$ were grown on MA at $10-12{ }^{\circ} \mathrm{C}$ for $3-5$ days (Bowman et al., 2003) and Fluviicola taffensis RW262 ${ }^{\mathrm{T}}$ was grown on $\mathrm{MA}$ (minus $\mathrm{NaCl}$ ) at $20^{\circ} \mathrm{C}$ for 3 days (O'Sullivan et al., 2005). Values given are percentages of total fatty acids. Fatty acids are designated as follows: total number of carbon atoms: number of double bonds, followed by the position of the double bond from the aliphatic end of the molecule. Prefixes i, a and $\mathrm{OH}$ represent iso-branched, anteiso-branched and hydroxy fatty acids, respectively. The suffix $c$ represents a cis isomer. ECL, Equivalent chain length; NA, not applicable (component of summed feature); tr, trace (less than $0 \cdot 1 \%$ ); - , not detected.

\begin{tabular}{|c|c|c|c|c|c|c|}
\hline Fatty acid & 1 & 2 & 3 & 4 & 5 & 6 \\
\hline $13: 0$ & $0 \cdot 1$ & - & $0 \cdot 5$ & - & - & $0 \cdot 1$ \\
\hline $14: 0$ & $1 \cdot 6$ & - & $1 \cdot 5$ & - & $0 \cdot 3$ & $3 \cdot 2$ \\
\hline $15: 0$ & - & - & $2 \cdot 9$ & $0 \cdot 8$ & $29 \cdot 3$ & $7 \cdot 5$ \\
\hline $16: 0$ & $0 \cdot 5$ & $0 \cdot 3$ & 1.9 & $0 \cdot 9$ & $1 \cdot 8$ & $3 \cdot 0$ \\
\hline $17: 0$ & - & - & - & - & - & $0 \cdot 2$ \\
\hline $18: 0$ & - & - & $0 \cdot 3$ & - & - & - \\
\hline i10:0 & - & $\operatorname{tr}$ & - & - & - & - \\
\hline i11:0 & $\operatorname{tr}$ & $0 \cdot 3$ & - & - & - & - \\
\hline i13:0 & $0 \cdot 3$ & - & $5 \cdot 6$ & - & - & - \\
\hline a13:0 & - & - & $\operatorname{tr}$ & - & - & - \\
\hline $13: 1$ at $12-13$ & $0 \cdot 1$ & - & - & - & - & - \\
\hline i14:0 & - & - & $0 \cdot 8$ & $13 \cdot 8$ & - & - \\
\hline i15:0 & $44 \cdot 0$ & $18 \cdot 7$ & $36 \cdot 4$ & $7 \cdot 8$ & $36 \cdot 3$ & $44 \cdot 2$ \\
\hline i15: 1 & $34 \cdot 8$ & $28 \cdot 0$ & - & - & - & - \\
\hline a $15: 0$ & - & - & $\operatorname{tr}$ & $5 \cdot 8$ & - & $0 \cdot 5$ \\
\hline i16:0 & $\operatorname{tr}$ & $\operatorname{tr}$ & $0 \cdot 6$ & $7 \cdot 8$ & $0 \cdot 4$ & $0 \cdot 6$ \\
\hline a16:0 & - & $0 \cdot 2$ & - & - & - & - \\
\hline i17:0 & - & - & - & - & - & $0 \cdot 1$ \\
\hline $\mathrm{i} 14: 1 \omega 9 c$ & - & - & $0 \cdot 4$ & $6 \cdot 8$ & $0 \cdot 7$ & $1 \cdot 0$ \\
\hline $\mathrm{i} 15: 1 \omega 10 c$ & - & - & - & $7 \cdot 1$ & $10 \cdot 9$ & $11 \cdot 8$ \\
\hline a $15: 1 \omega 10 c$ & - & - & $45 \cdot 0$ & $8 \cdot 2$ & - & - \\
\hline $\mathrm{i} 16: 1 \omega 6 c$ & - & - & $0 \cdot 5$ & - & - & - \\
\hline $\mathrm{i} 16: 1 \omega 11 c$ & - & - & - & $2 \cdot 9$ & $0 \cdot 3$ & $0 \cdot 7$ \\
\hline $\mathrm{i} 17: 1 \omega 5 c$ & $0 \cdot 5$ & - & - & - & - & - \\
\hline $\mathrm{i} 17: 1 \omega 9 c$ & - & $7 \cdot 3$ & - & - & - & - \\
\hline $\mathrm{i} 17: 1 \omega 12 c$ & - & - & - & - & $0 \cdot 7$ & - \\
\hline $\mathrm{i} 17: 1 \omega 13 c$ & - & - & - & - & $0 \cdot 2$ & - \\
\hline a17: $1 \omega 13 c$ & - & - & - & - & $\operatorname{tr}$ & - \\
\hline $15: 1 \omega 4 c$ & - & - & - & - & $\operatorname{tr}$ & - \\
\hline $15: 1 \omega 6 c$ & - & $1 \cdot 3$ & - & - & - & - \\
\hline $15: 1 \omega 8 c$ & - & - & $1 \cdot 4$ & - & - & - \\
\hline $15: 1 \omega 11 c$ & - & - & - & - & $8 \cdot 3$ & $1 \cdot 2$ \\
\hline $16: 1 \omega 5 c$ & - & - & - & - & $\operatorname{tr}$ & - \\
\hline $16: 1 \omega 7 c$ & NA & NA & $1 \cdot 5$ & - & - & - \\
\hline $16: 1 \omega 12 c$ & - & - & - & - & $4 \cdot 4$ & $4 \cdot 9$ \\
\hline
\end{tabular}

Table 2. cont.

\begin{tabular}{|c|c|c|c|c|c|c|}
\hline Fatty acid & 1 & 2 & 3 & 4 & 5 & 6 \\
\hline $17: 1 \omega 13 c$ & - & - & - & - & $2 \cdot 1$ & $0 \cdot 7$ \\
\hline $18: 1 \omega 5 c$ & - & $0 \cdot 3$ & - & - & - & - \\
\hline $18: 1 \omega 7 c$ & - & - & $0 \cdot 3$ & - & - & - \\
\hline $18: 1 \omega 9 c$ & - & - & $0 \cdot 4$ & - & - & - \\
\hline 2-OH i14:0 & - & - & - & $6 \cdot 7$ & - & - \\
\hline $2-\mathrm{OH} 15: 0$ & - & $3 \cdot 0$ & - & - & - & - \\
\hline 2-OH i15:0 & NA & NA & - & $1 \cdot 6$ & - & $3 \cdot 5$ \\
\hline $2-\mathrm{OH}$ a15:0 & - & - & - & $18 \cdot 4$ & - & - \\
\hline 3-OH i14:0 & $\operatorname{tr}$ & - & - & - & - & - \\
\hline $3-\mathrm{OH} 15: 0$ & - & $1 \cdot 0$ & - & - & $\operatorname{tr}$ & - \\
\hline 3-OH i15:0 & $2 \cdot 5$ & $4 \cdot 9$ & - & - & $1 \cdot 0$ & $0 \cdot 5$ \\
\hline $3-\mathrm{OH} 16: 0$ & $0 \cdot 5$ & - & - & $2 \cdot 9$ & - & - \\
\hline $3-\mathrm{OH}$ i16:0 & $0 \cdot 4$ & $0 \cdot 2$ & - & $6 \cdot 8$ & $\operatorname{tr}$ & $4 \cdot 2$ \\
\hline $3-\mathrm{OH} 17: 0$ & - & $1 \cdot 2$ & - & - & $\operatorname{tr}$ & - \\
\hline 3-OH i17:0 & $9 \cdot 3$ & $18 \cdot 1$ & - & - & $3 \cdot 3$ & $12 \cdot 3$ \\
\hline 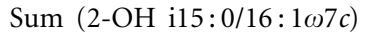 & $2 \cdot 0$ & $10 \cdot 0$ & - & - & - & - \\
\hline Sum (i16:1/3-OH 14:0) & $\operatorname{tr}$ & - & - & - & - & - \\
\hline Unknown ECL $11 \cdot 543$ & $0 \cdot 3$ & $0 \cdot 4$ & - & - & - & - \\
\hline Unknown ECL $13 \cdot 565$ & $2 \cdot 2$ & $4 \cdot 5$ & - & - & - & - \\
\hline Unknown ECL $16 \cdot 582$ & $0 \cdot 8$ & $0 \cdot 2$ & - & - & - & - \\
\hline
\end{tabular}

$9 \cdot 0$ with optimum growth at around $\mathrm{pH} 7 \cdot 0$. The strain was halophilic, growing between $1 \cdot 0$ and $7 \cdot 5 \%(\mathrm{w} / \mathrm{v}) \mathrm{NaCl}$, with optimum growth at $1-3 \%$. Cells contained carotenoid pigments with major absorption peaks at 446, 471 and $502 \mathrm{~nm}$. The isoprenoid quinone of UST040201-001 ${ }^{\mathrm{T}}$ was MK-6, which matches the major respiratory quinone of members of the family Flavobacteriaceae (Bernardet et al., 2002). The DNA G $+\mathrm{C}$ content of UST040201-001 ${ }^{\mathrm{T}}$ was $35 \cdot 8 \pm 0 \cdot 5 \mathrm{~mol} \%$, which is within the range of values for members of the family Cryomorphaceae (35-40 mol\%). Table 1 lists the phenotypic features analysed.

The fatty acid profile of UST040201-001 ${ }^{\mathrm{T}}$ and those of phylogenetically related members of the family Cryomorphaceae are given in Table 2. Strain UST040201$001^{\mathrm{T}}$ contained three major fatty acids: i15:0 (44.0\%), i15: $1(34 \cdot 8 \%)$ and 3-OH i17:0 $(9 \cdot 3 \%)$, which accounted for $89 \%$ of the total fatty acids. Similar to other members of the family Cryomorphaceae (Bowman et al., 2003; O'Sullivan et al., 2005), UST040201-001 ${ }^{\mathrm{T}}$ possessed high levels of $\mathrm{C}_{13}-$ $\mathrm{C}_{17}$ branched-chain fatty acids $(79 \cdot 7 \%)$. The fatty acid profile of UST040201-001 ${ }^{\mathrm{T}}$ showed more similarity to that of Owenweeksia hongkongensis UST20020801 ${ }^{\mathrm{T}}$, but differed in the content of $14: 0, \mathrm{i} 15: 0,3-\mathrm{OH}$ i1 $5: 0$ and $3-\mathrm{OH}$ i17 $: 0$. In summary, the fatty acid profile of strain UST040201-001 ${ }^{\mathrm{T}}$ differed significantly from those of other members of the family Cryomorphaceae (Table 2).

The 16S rRNA gene sequence of strain UST040201-001 ${ }^{\mathrm{T}}$ (1504 nt) shared $89 \cdot 2 \%$ similarity with that of Crocinitomix catalasitica NCIMB $1418^{\mathrm{T}}$ (Bowman et al., 2003). Phylogenetic analysis showed that strain UST20020801 ${ }^{\mathrm{T}}$ formed a distinct lineage within the family Cryomorphaceae 
Table 3. Characteristics that differentiate strain UST040201-001 ${ }^{\top}$ from the type species of other genera of the family Cryomorphaceae

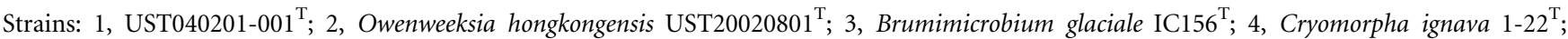
5, Crocinitomix catalasitica NCIMB $1418^{\mathrm{T}}$; 6, Fluviicola taffensis RW262 ${ }^{\mathrm{T}}$. Data are from Bowman et al. (2003), Lau et al. (2005), O'Sullivan et al. (2005) and this study. +, Positive; -, negative; V, variable; W, weak; ND, data not available. All strains are positive for catalase.

\begin{tabular}{|c|c|c|c|c|c|c|}
\hline Characteristic & 1 & 2 & 3 & 4 & 5 & 6 \\
\hline Habitat & Marine & Marine & Marine & Marine & Marine & Freshwater \\
\hline Length of cells $(\mu \mathrm{m})$ & $0 \cdot 5-3 \cdot 8$ & $0 \cdot 5-4$ & $1-3$ & $0 \cdot 5-3$ & $3-100$ & $1 \cdot 5-5 \cdot 7$ \\
\hline Colour of cell mass ${ }^{\star}$ & $\mathrm{O}$ & $\mathrm{O}$ & $\mathrm{O}$ & $\mathrm{O}$ & Y & $\mathrm{O}-\mathrm{Y}$ \\
\hline \multicolumn{7}{|l|}{ Growth on/at: } \\
\hline $25^{\circ} \mathrm{C}$ & + & + & $\mathrm{v} / \mathrm{w}$ & - & + & + \\
\hline $35^{\circ} \mathrm{C}$ & + & + & - & - & - & - \\
\hline $5 \% \mathrm{NaCl}$ & + & + & + & - & + & - \\
\hline $7 \cdot 5 \% \mathrm{NaCl}$ & + & + & - & - & - & - \\
\hline Metabolism $\dagger$ & A & A & $\mathrm{F}$ & A & A & A \\
\hline Oxidase & + & + & - & - & - & - \\
\hline Flexirubin reaction & - & - & - & - & - & + \\
\hline Glucose utilization & - & - & + & - & - & - \\
\hline \multicolumn{7}{|l|}{ Degradation of: } \\
\hline Gelatin & + & + & - & - & - & $\mathrm{W}$ \\
\hline Casein & + & - & - & - & - & ND \\
\hline DNase & - & - & $\mathrm{V}$ & - & - & + \\
\hline Phosphatase & + & + & + & - & + & ND \\
\hline Nitrate reductase & - & - & + & - & - & - \\
\hline DNA $G+C$ content $(\mathrm{mol} \%)$ & $35 \cdot 8 \pm 0 \cdot 5$ & $39-40$ & $38-40$ & $36-37$ & 35 & $37 \cdot 2$ \\
\hline
\end{tabular}

${ }^{*} \mathrm{O}$, Orange; Y, yellow.

$\dagger$ A, Strictly aerobic; F, facultatively anaerobic.

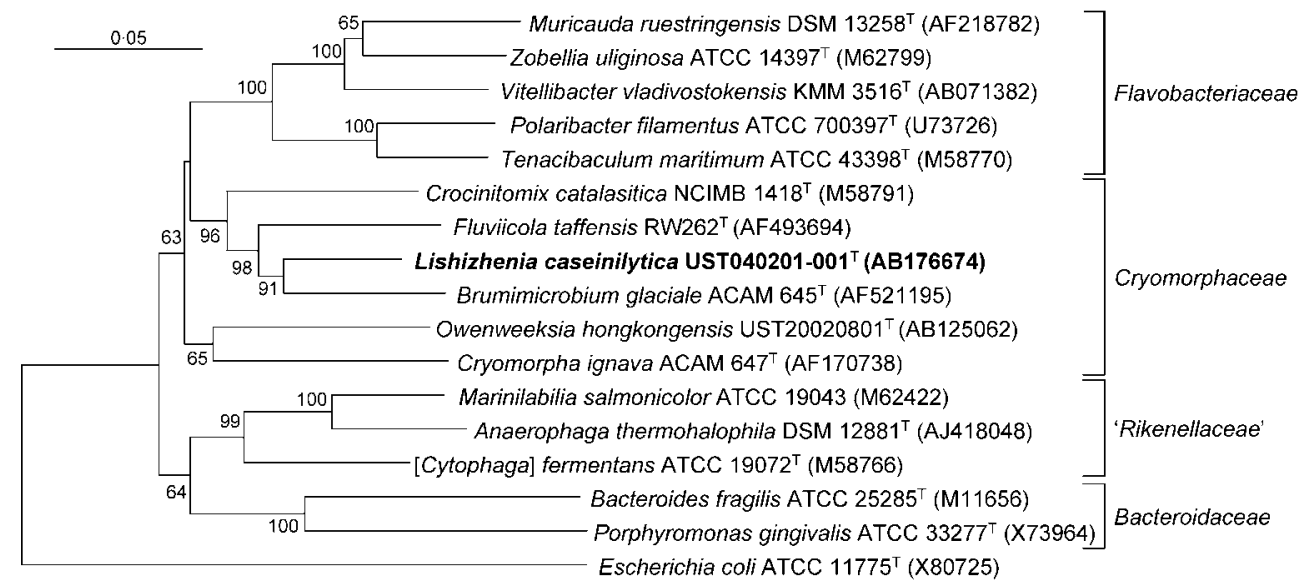

Fig. 1. Phylogenetic relationship of strain UST040201-001 ${ }^{\top}$ and related taxa within the phylum Bacteroidetes based on $16 \mathrm{~S}$ rRNA gene sequences. The tree was created by using the neighbour-joining method and percentages at nodes represent levels of bootstrap support from 1000 resampled datasets. Escherichia coli ATCC $11775^{\top}$ was used as the outgroup. Bar, 0.05 nucleotide substitutions per position. 
and linked to Brumimicrobium glaciale $\mathrm{IC} 156^{\mathrm{T}}$ with bootstrap support of $91 \%$ by the neighbour-joining algorithm (Fig. 1) and $80 \%$ by the maximum-parsimony analysis (data not shown). Sequence similarities to other members of the family Cryomorphaceae were less than $91 \%$ (Brumimicrobium glaciale $\mathrm{IC} 156^{\mathrm{T}}, 90 \cdot 1 \%$; Fluviicola taffensis $\quad$ RW262 ${ }^{\mathrm{T}}$ 89.6\%; Owenweeksia hongkongensis UST20020801 $1^{\mathrm{T}}, 87 \cdot 3 \%$; Cryomorpha ignava $1-22^{\mathrm{T}}$, $86 \cdot 3 \%$ ), indicating that strain UST040201-001 ${ }^{\mathrm{T}}$ is distantly related to them at the genus level.

Strain UST040201-001 ${ }^{\mathrm{T}}$ displayed some common phenotypic traits of the Cryomorphaceae: rod- to filamentousshaped cells, possession of carotenoid or flexirubin pigments, ability to perform aerobic respiration, requirement for complex organic growth factors like yeast extract or peptone and inability to utilize carbohydrates, arginine, agar and starch. UST040201-001 ${ }^{\mathrm{T}}$ could be differentiated from other members of the family Cryomorphaceae by several phenotypic tests (Table 3): from Owenweeksia hongkongensis UST20020801 ${ }^{\mathrm{T}}$ by its caseinase activity and its lower DNA $\mathrm{G}+\mathrm{C}$ content; from Fluviicola taffensis $\mathrm{RW} 262^{\mathrm{T}}$ by its requirement for $\mathrm{Na}^{+}$ions, the presence of oxidase, absence of DNase and susceptibility to chloramphenicol; and from Brumimicrobium glaciale $\mathrm{IC} 156^{\mathrm{T}}$, Crocinitomix catalasitica NCIMB $1418^{\mathrm{T}}$ and Cryomorpha ignava $1-22^{\mathrm{T}}$ by its ability to grow at $35^{\circ} \mathrm{C}$, tolerance of $7 \cdot 5 \% \mathrm{NaCl}$ and presence of oxidase.

On the basis of the characteristics described above, we propose that the strain UST040201-001 ${ }^{\mathrm{T}}$ should be placed in a new genus as a representative of a novel species, Lishizhenia caseinilytica gen. nov., sp. nov.

\section{Description of Lishizhenia gen. nov.}

Lishizhenia [Li.shi.zhe' ni.a. N.L. fem. n. Lishizhenia after Li Shizhen (1518-1593), the famous Chinese naturalist].

Cells are Gram-negative, halophilic, heterotrophic, nonflagellated and motile flexible short rods, which divide by binary fission. Cells do not form spores, are strictly aerobic and require $\mathrm{Na}^{+}$, sea salts and organic growth factors such as yeast extract or peptone for growth. Cells do not utilize carbohydrates. Cells contain oxidase, catalase and alkaline phosphatase. Major respiratory quinone is MK-6. Predominant fatty acids are i15:0, i15:1,3-OH

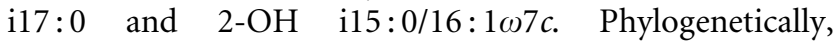
Lishizhenia is a member of the family Cryomorphaceae in the phylum Bacteroidetes. The type species is Lishizhenia caseinilytica.

\section{Description of Lishizhenia caseinilytica sp. nov.}

Lishizhenia caseinilytica (ca.sei.ni.ly'ti.ca. N.L. n. caseinum casein; N.L. fem. adj. lytica dissolving from Gr. v. lyein to dissolve; N.L. fem. adj. caseinilytica casein-dissolving).

Exhibits the following properties in addition to those given in the genus description. Cells are about $0 \cdot 3-0 \cdot 5 \mu \mathrm{m}$ in diameter and $0 \cdot 5-3 \cdot 8 \mu \mathrm{m}$ in length. Enlarged cells and filamentous cells are seen occasionally in stationary phase in broth culture. Colonies are light orange, circular, convex, smooth, glistening and translucent with an entire margin. Cells are motile by gliding but do not swarm on MA. Mesophilic, growing between 4 and $37^{\circ} \mathrm{C}$ with optimum growth at $27-30{ }^{\circ} \mathrm{C}$. Growth occurs between $\mathrm{pH} 5 \cdot 0$ and $9 \cdot 0$ with optimum growth at around $\mathrm{pH} 7 \cdot 0$. Halophilic, growing between 1.0 and $7 \cdot 5 \%(\mathrm{w} / \mathrm{v}) \mathrm{NaCl}$ with optimum growth at $1-3 \%$. Cells possess carotenoid pigments. Other physiological and biochemical properties are listed in Table 1 . The fatty acid profile of the type strain is given in Table 2. Sensitive to ampicillin $(10 \mu \mathrm{g})$, chloramphenicol $(30 \mu \mathrm{g})$, penicillin $\mathrm{G}(2 \mathrm{U})$, rifampicin $(10 \mu \mathrm{g})$, tetracycline $(30 \mu \mathrm{g})$ and polymyxin $\mathrm{B}(300 \mathrm{U})$ but resistant to kanamycin $(10 \mu \mathrm{g})$, gentamicin sulfate $(10 \mu \mathrm{g})$ and spectinomycin $(10 \mu \mathrm{g})$. The DNA G $+\mathrm{C}$ content of the type strain is $35 \cdot 8 \pm 0 \cdot 5 \mathrm{~mol} \%$.

The type strain is UST040201-001 ${ }^{\mathrm{T}} \quad(=\mathrm{NRRL}$ B$41434^{\mathrm{T}}=\mathrm{JCM} 13821^{\mathrm{T}}$ ), which was isolated from a sample of sand-filtered seawater collected at Port Shelter, adjacent to the Coastal Marine Laboratory, Hong Kong University of Science and Technology.

\section{Acknowledgements}

We sincerely thank Professor Hans G. Trüper for valuable suggestions on the etymology, Mr Tze Kin Cheung for transmission electron microscopy, Dr Xiancui Li for DNA G + C analysis and Mr Simon Lau for antibiotic disc-diffusion assays. This work was supported by grants R5498, CMI03/04.SC03, CAS-CF03/04.SC01 and CA04/05.SC01.

\section{References}

Baumann, P. \& Baumann, L. (1981). The marine Gram-negative eubacteria: genera Photobacterium, Beneckea, Alteromonas, Pseudomonas and Alcaligenes. In The Prokaryotes, vol. 1, pp. 1302-1331. Edited by M. P. Starr, H. Stolp, H. G. Trüper, A. Balows \& H. Schlegel. Berlin: Springer.

Bernardet, J. F., Nakagawa, Y. \& Holmes, B. (2002). Proposed minimal standards for describing new taxa of the family Flavobacteriaceae and emended description of the family. Int J Syst Evol Microbiol 52, 1049-1070.

Bowman, J. P., Nichols, C. M. \& Gibson, J. A. (2003). Algoriphagus ratkowskyi gen. nov., sp. nov., Brumimicrobium glaciale gen. nov., sp. nov., Cryomorpha ignava gen. nov., sp. nov. and Crocinitomix catalasitica gen. nov., sp. nov., novel flavobacteria isolated from various polar habitats. Int J Syst Evol Microbiol 53, 1343-1355.

Collins, M. D. (1994). Isoprenoid quinones. In Chemical Methods in Prokaryotic Systematics, pp. 265-309. Edited by M. Goodfellow \& A. G. O'Donnell. Chichester: Wiley.

Collins, C. H., Lyne, P. M. \& Grange, J. M. (1989). Collins and Lyne's Microbiological Methods. London \& Boston: Butterworth.

Fautz, E. \& Reichenbach, H. (1980). A simple test for flexirubin-type pigments. FEMS Microbiol Lett 8, 87-91.

Felsenstein, J. (1985). Confidence limits on phylogenies: an approach using the bootstrap. Evolution 39, 783-791.

Gosink, J. J., Woese, C. R. \& Staley, J. T. (1998). Polaribacter gen. nov., with three new species, $P$. irgensii sp. nov., $P$. franzmannii sp. 
nov. and $P$. filamentus sp. nov., gas vacuolate polar marine bacteria of the Cytophaga-Flavobacterium-Bacteroides group and reclassification of 'Flectobacillus glomeratus' as Polaribacter glomeratus comb. nov. Int J Syst Bacteriol 48, 223-235.

Grossart, H. P., Levold, F., Allgaier, M., Simon, M. \& Brinkhoff, T. (2005). Marine diatom species harbour distinct bacterial communities. Environ Microbiol 7, 860-873.

Hall, T. A. (1999). BioEdit: a user-friendly biological sequence alignment editor and analysis program for Windows 95/98/NT. Nucleic Acids Symp Ser 41, 95-98.

Kimura, M. (1980). A simple method for estimating evolutionary rates of base substitutions through comparative studies of nucleotide sequences. J Mol Evol 16, 111-120.

Kumar, S., Tamura, K., Jakobsen, I.-B. \& Nei, M. (2001). MEGA2: molecular evolutionary genetics analysis software. Bioinformatics $\mathbf{1 7}$, 1244-1245.

Lane, D. J. (1991). 16S/23S rRNA sequencing. In Nucleic Acid Techniques in Bacterial Systematics, pp. 115-175. Edited by E. Stackebrandt \& M. Goodfellow. New York: Wiley.

Lau, K. W., Ng, C. Y., Ren, J., Lau, S. C., Qian, P. Y., Wong, P. K., Lau, T. C. \& Wu, M. (2005). Owenweeksia hongkongensis gen. nov., sp. nov., a novel marine bacterium of the phylum 'Bacteroidetes'. Int J Syst Evol Microbiol 55, 1051-1057.

Lewin, R. A. \& Lounsbery, D. M. (1969). Isolation, cultivation and characterization of flexibacteria. J Gen Microbiol 58, 145-170.

Mesbah, M., Premachandran, U. \& Whitman, W. B. (1989). Precise measurement of the $\mathrm{G}+\mathrm{C}$ content of deoxyribonucleic acid by highperformance liquid chromatography. Int J Syst Bacteriol 39, 159-167.
Nakagawa, Y. \& Yamasato, K. (1993). Phylogenetic diversity of the genus Cytophaga revealed by $16 \mathrm{~S}$ rRNA sequencing and menaquinone analysis. J Gen Microbiol 139, 1155-1161.

O’Sullivan, L. A., Rinna, J., Humphreys, G., Weightman, A. J. \& Fry, J. C. (2005). Fluviicola taffensis gen. nov., sp. nov., a novel freshwater bacterium of the family Cryomorphaceae in the phylum 'Bacteroidetes'. Int J Syst Evol Microbiol 55, 2189-2194.

Pinhassi, J., Sala, M. M., Havskum, H., Peters, F., Guadayol, O., Malits, A. \& Marrase, C. (2004). Changes in bacterioplankton composition under different phytoplankton regimens. Appl Environ Microbiol 70, 6753-6766.

Reichenbach, H. (1989). Family I. Cytophagaceae Stanier 1940, 630, ${ }^{\mathrm{AL}}$ emend. In Bergey's Manual of Systematic Bacteriology, vol. 3, pp. 2013-2015. Edited by J. T. Staley, M. P. Bryant, N. Pfennig \& J. G. Holt. Baltimore: Williams \& Wilkins.

Saitou, N. \& Nei, M. (1987). The neighbor-joining method: a new method for reconstructing phylogenetic trees. Mol Biol Evol 4, 406-425.

Smibert, R. M. \& Krieg, N. R. (1994). Phenotypic characterization. In Methods for General and Molecular Bacteriology, pp. 607-654. Edited by P. Gerhardt, R. G. E. Murray, W. A. Wood \& N. R. Krieg. Washington, DC: American Society for Microbiology.

Thompson, J. D., Gibson, T. J., Plewniak, F., Jeanmougin, F. \& Higgins, D. G. (1997). The CLUSTAL_X windows interface: flexible strategies for multiple sequence alignment aided by quality analysis tools. Nucleic Acids Res 25, 4876-4882.

Zhang, Z., Schwartz, S., Wagner, L. \& Miller, W. (2000). A greedy algorithm for aligning DNA sequences. J Comput Biol 7, 203-214. 